\title{
PANDANGAN ORIENTALISTERHADAP IDENTITAS DAN ISU POLITIK TOKOH PEREMPUAN DALAM PUTRI CINA
}

\author{
THE ORIENTALIST VIEWS OF IDENTITY AND POLITICAL ISSUES \\ IN WOMEN 'S FIGURE 'PRINCESS OF CHINA'
}

\author{
R. Myrna Nur Sakinah \\ Program Pascasarjana Sastra Kontemporer Universitas Padjadjaran Bandung \\ Jalan Raya Bandung-Sumedang km. 21 \\ e-mail: queen_umiersa@yahoo.co.id
}

\begin{abstract}
Abstrak
Penelitian ini membahas dua permasalahan tentang pandangan orientalis terhadap identitas dan isu politik yang terdapat pada novel Putri Cina karya Sindhunata. Karya ini memiliki kekuatan dalam mengungkap identitas dan isu politik. Hal ini dipengaruhi oleh tradisi dan posisi Putri Cina di tengah masyarakat Jawa dan Cina. Penelitian ini berfokus pada kajian Postkolonial yang dikemukakan oleh Edward Said (1978). Hubungan kisah traumatik menjadi perempuan yang sama-sama mengalami kepedihan ini dianggap sebagai cara untuk memahami hal yang tidak dikenal dan dapat dikatakan sebagai sebuah proyeksi psikologis terhadap dunia eksternal. Dalam pendekatan ini peneliti akan menggunakan penelitian pendekatan kritik secara objektif. Itu berarti bahwa peneliti akan menekankan struktur karya sastra dalam pengembangan dunia pengarang, publik pembaca, dan situasi zaman yang melahirkan karya sastra tersebut. Dari hasil analisis ditemukan penilaian orientalis yang diperankan oleh tokoh perempuan pada novel Putri Cina karya Shindunata ini direpresentasikan dalam eksistensinya di tengah masyarakat Jawa dan Cina sebagai tokoh perempuan yang mencitrakan identitasnya dengan citra perempuan secara fisik, perilaku, psikis, dan sosial.
\end{abstract}

Kata kunci: ras, eksistensi, identitas, dan orientalis.

\section{Abstract}

Two subjects in this research were about the orientalist view of identity and political issue in Putri Cina novel of Sindhunata. The power of this work was on revealing the identity and political issues, influenced by the hierarchy position of Chinese princess in the middle of Javanese and Chinese society. This research focused on Postcolonial discussion by Edward Said (1978). The traumatic relationship being the tragic women was considered as a way in understanding the unknown and can be said as a psychology reflection toward the external world. The writer implemented critical approach objectively, means that the writer concerned on the structure of literary work in developing the world of authority, reader, and the situation of particular era. The result found that the orientalist judgment of a woman character in Putri Cina of Shindunata represented her existences in the middle of Javanese and Chinese society as a woman who identified herself physically, attitude, and social.

Keywords: race, existence, identity, and orientalist. 


\section{A. PEN DAHULUAN}

Budaya adalah sebuah sistem yang mempunyai koherensi. Bentuk-bentuk simbolis yang berupa kata, benda, laku, mite, sastra, lukisan, nyanyian, musik, kepercayaan mempunyai kaitan erat dengan konsep-konsep epistemologis dari sistem pengetahuan masyarakatnya (Kuntowijoyo, 2006: xi).

Dalam pengantarnya, Kuntowijoyo (2006: 5) menambahkan bahwa sistem budaya sebenarnya penuh dengan kompleksitas yang tidak mudah dipahami secara sekilas. Analisis budaya seharusnya mencoba untuk melakukan pendekatan berbagai disiplin ilmu supaya dapat menjelaskan gejala-gejala budaya.

Perempuan Cina yang berada di Indonesia, khususnya yang menempati wilayah tanah Jawa merupakan sebagian dari masyarakat Indonesia yang heterogen. Perempuan Cina memiliki citra atau gambaran yang dapat dilihat dari fisik, perilaku, kejiwaan, dan tanggapan masyarakat. Dalam bermasyarakat, perempuan Cina juga memiliki peranan penting dalam proses pembauran karena syarat dari terbentuknya masyarakat yang heterogen adalah mereka yang dapat saling melengkapi satu dengan yang lain.

Novel Putri Cina karya Sindhunata ini menggambarkan bagaimana kedudukan perempuan Cina yang berada di tengah masyarakat yang identitasnya selalu diragukan. Pencarian jati diri merupakan tujuan utamanya dalam upaya mencari identitas keberadaanya. Keberadaan perempuan Cina dalam novel Putri Cina ini selalu dianggap remeh dan dianggap sebagai warga yang tidak mempunyai tanah air, bahkan keberadaannya merupakan satu malapetaka besar bagi rakyatnya. Keberadaanya merupakan tumbal dari segala malapetaka. Permasalahannya terletak pada identitas diri perempuan Cina dan isu politiknya.

Penelitian ini mengkaji keberlakuan teori postkolonial dengan mengungkap jawaban dari permasalahan identitas dan isu politik pada dua tokoh perempuan "Putri Cina dan Giok Tien" dalam novel Putri Cina. Kedua perempuan Cina ini akan dijadikan sebagai subjek penelitian. Melalui subjek penelitian perempuan Cina, penelitian ini akan memposisikan dirinya dalam konteks yang lebih luas dalam wacana identitas.

Penelitian ini akan merepresentasikan bagaimana identitas diri perempuan Cina yang selalu mendefinisikan diri dan darahnya dalam upaya pencarian jati dirinya. Berbagai situasi politik terjadi pada kedua tokoh perempuan "Putri Cina dan Giok Tien". Menurut Sugihastuti (2003:193), citra perempuan memiliki pengertian sebagai semua wujud gambaran mental spiritual dan tingkah laku keseharian perempuan yang menunjukkan wajah dan ciri khas dari perempuan. Shindunata, dalam persepsi saya, ingin menampilkan bagaimana pencitraan perempuan "Putri Cina dan Giok Tien" dalam keadaan dirinya yang selalu mempermasalahkan identitas dan keberadaan dirinya di tengah masyarakat yang berbeda darah dan kulit.

Pencarian identitas dan pembahasan isu politik merupakan sebagian wacana dari wacana postkolonial. Berbicara tentang penjajah dan yang terjajah seringkali tidak mudah untuk bisa dikategorikan. Wacana postkolonial secara umum dapat dipahami sebagai wacana identitas dari kelompok marjinal. Kelompok marjinal adalah subaltern. Kelompok subaltern adalah mereka yang disubordinasikan oleh struktur kekuasaan yang dominan dan dipinggirkan dari representasi politik (Lim Sing Meij, 2009:18).

Lim Sing Meij (2009:21) mengistilahkan postkolonial dengan menggunakan kata pasca, ia berpendapat bahwa wacana pascakolonial adalah sebuah wacana tentang kebangkitan orangorang yang teralienasi, warga negara kelas dua yang ingin menyatakan kemerdekaannya dari wacana dominan di mana identitas mereka ditentukan oleh pihak luar. Menurutnya, persoalan identitas 
merupakan isu kunci dalam wacana postkolonial.

Berpijak pada uraian yang diuraikan dalam latar belakang di atas, maka pokok bahasan inti penelitian ini mengenai identitas dan isu politik pada tokoh perempuan "Putri Cina dan Giok Tien" dalam novel Putri Cina karya Shindunata. Secara substantif penelitian ini bertujuan untuk mengetahui proses tentang representasi perempuan yang tampil dalam melakukan konstruksi identitas perempuan dan isu politik yang terkandung dalam novel Putri Cina. Penelitian terhadap novel karya Shindunata ini akan membawa penelitian pada titik bagaimana sudut pandang masyarakat dalam menanggapi gerakan postkolonialisme lahir sebagaimana postmodernisme, memiliki sifat kontinuitas dalam bentuk yang lebih signifikan.

Dalam penelitian ini, Identitas Diri dan Isu Politik Pada Tokoh Perempuan "Putri Cina dan Giok Tien" dalam novel "Putri Cina" karya Shindunata", akan dianalisis dan diinterpretasi melalui kritik sastra postkolonial. Rene Wellek (1956:39) menyatakan bahwa literary critisism is frequently used in such a way as to include all literary theory; but such usage ignores a useful distinction. Wellek menyimpulkan bahwa kritik sastra berarti pembicaraan tentang karya sastra tertentu. Dalam pendekatan ini peneliti akan menggunakan penelitian pendekatan kritik secara objektif. Itu berarti bahwa peneliti akan menekankan struktur karya sastra dalam pengembangan dunia pengarang, publik pembaca, dan situasi zaman yang melahirkan karya sastra tersebut.

Berdasarkan latar belakang di atas bahwa penelitian akan membahas dua permasalahan, menemukan identitas dan isu politik tokoh perempuan "Putri Cina" dan "Giok Tien" dalam novel Putri Cina karya Shindunata.

\section{B. METODE PEN ELITIA N}

Dalam hal ini penelitian yang akan digunakan adalah studi kepustakaan (library research). Hal ini bertujuan untuk mengumpulkan karya sastra yang dijadikan objek penelitian; mengumpulkan ulasan atau pembahasan yang berkaitan dengan objek; mengumpulan penelitian-penelitian yang ada hubungannya dengan teks. Pada tahapan analisis data, digunakan metode deskripif analitik. Metode ini digunakan dengan cara mendeskripsikan data yang kemudian disusul dengan analisis (Ratna, 2004:53).

Hal senada juga diungkapkan Nazir (1988:65) bahwa metode deskriptif analitik bertujuan untuk membuat deskripsi, gambaran, atau uraian secara sistematis, faktual, dan akurat mengenai fakta-fakta, sifat-sifat, serta hubungan antarfenomena yang diselidiki. Tahapan terakhir dari seluruh proses penelitian adalah penyajian analisis data. Hasil analisis data dapat digunakan dengan berupa jurnal ilmiah. Metode seperti ini disebut sebagai metode penelitian naratif (Ratna, 2004:5). Menurut Ratna metode naratif ini disampaikan melalui kata-kata biasa. Penerapan metode ini digunakan untuk memahami kajian teologi.

Teori yang dipakai dalam tulisan ini adalah teori postkolonial yang diperkenalkan oleh Edward Said (1978) dalam bukunya yang berjudul Orientalism. Menurut Said (1978:120), orientalisme adalah ilmu dengan kepentingan untuk "menguasai" bangsa-bangsa di luar Barat. Pendekatan library research ini digunakan karena bersangkutan pula dengan teori yang digunakan.

\section{Landasan Teori: Kajian Postkolonial Identitas Diri dan Isu Politik}

Postkolonial merupakan kajian terhadap karya-karya sastra dan bidang yang lain yang berkaitan dengan praktik kolonialisme atau imperialisme baik secara sinkronik maupun diakronik. Kajian postkolonial berusaha membongkar selubung praktik kolonialisme di balik sejumlah karya sastra sebagai superstruktur dari suatu kekuasaan, kekuasaan kolonial. Sastra dipandang memiliki kekuatan baik 
sebagai pembentuk hegemoni kekuasan. Menurut Ratna dalam menanggapi Gramsci (2010: 183), ada tiga cara untuk membentuk gagasan, yaitu bahasa, pendapat umum (common sense), dan folklor.

Ketiga komponen ini merupakan komponen yang berpengaruh dalam memerankan ideologi untuk menemukan identitas. Bahasa merupakan konsep utama dalam berkomunikasi, pendapat umum merupakan tempat berkumpulnya ideologi yang bersifat setara dan berlawanan, sedangkan folklor merupakan kepercayaan rakyat atau cerita rakyat yang diwariskan secara turun temurun juga berperan dalam memerankan hegemoni yang berfungsi sebagai pengikat ideologi masyarakat tanpa ada rasa keterpaksaan.

Menurut Said (1978) teori postkolonial itu sendiri merupakan seperangkat teori dalam bidang filsafat, film, sastra, dan bidang-bidang lain yang mengkaji legalitas budaya yang terkait dengan peran kolonial. Bidang ini bukanlah menjadi monopoli kajian sastra. Postkolonial mirip dengan kajian feminisme yang meliputi bidang kajian humaniora yang lebih luas; sejajar dengan kajian postmodernisme atau postrukturalisme. Said (1978:120) menjelaskan berbagai wacana orientalis dalam setiap bab tulisannya. Dalam bab pertama, ia menguraikan bagaimana wacana Orientalis dipindahkan dari satu negara ke negara dan dari pemimpin politik untuk para penulis. Dia menyarankan bahwa wacana ini didirikan sebagai dasar untuk semua (atau hampir semua) studi lebih lanjut dan wacana dari Orient oleh Barat. Dalam bab kedua, ia menyatakan bahwa ada empat unsur yang ia kemukakan dalam pemikiran abad kedelapan belas berkaitan dengan ekspansi, konfrontasi sejarah, simpati, dan klasifikasi. Terakhir, ia menguraikan Orientalisme memiliki kerangka sejarah. Dalam hal ini Said (1978:325) mewacanakan tentang keseluruhan mengenai wacana budaya atau pun gagasan dari budaya yang berbeda seperti halnya ras, agama, dan peradaban.

Postkolonial merupakan sebuah bidang kajian yang memusatkan perhatian pada dampak-dampak kolonialisasi terhadap suatu bangsa. Dampak-dampak tersebut dapat berupa perubahan pada aspek sosial, politik, ekonomi serta budaya suatu bangsa sehingga memunculkan permasalahan identitas. Permasalahan tersebut disebabkan adanya pemikiran mengenai konsep superioritas dan inferioritas. Superioritas seringkali dikaitkan dengan 'colonizer' yang cenderung ditujukan pada orang berkulit putih atau bangsa Eropa. Sementara itu, inferioritas dikaitkan pada 'colonized' atau orang-orang yang bukan Eropa dengan ciri khas kulit berwarna sebagaimana yang dimiliki bangsa Asia. Oleh karena itu, kajian ini dimaksudkan untuk mengetahui kondisi yang dialami suatu masyarakatatau individu—setelah mengalami kolonialisasi.

Orientalisme merupakan sebuah istilah yang dimunculkan Edward Said (1978); dia menyebutkan bahwa “...Orientalism. a way of coming to terms with the Orient that is based on the Orient's special place in European Western experience." (1979: 1). Istilah Orient sendiri cenderung dipahami dan dipakai bangsa Eropa untuk menunjukkan wilayah geografis yang terdapat di bagian Timur. Menurut Said, Orient melebihi batas-batas geografis sebab wilayah tersebut memiliki sumber daya alam yang berlimpah dan budaya untuk membangun peradaban sejak koloni terdahulu sehingga menjadi pembeda bagi kaum Orient (1979: 1). Kawasan Asia yang berada di Timur menjadi wilayah koloni imperium Eropa, terutama Inggris dan Perancis. Beberapa kawasan tersebut memiliki koloni terbesar karena memiliki sumber daya alam yang berlimpah sehingga mampu menopang perekonomian koloni dan imperium pada zamannya.

Lebih lanjut Said (1978:220) mengatakan bahwa perbedaan Barat dan 
Timur menjadi satu implikasi wacana yang secara intens membentuk perbedaan ideologi Barat dan Timur baik sebagai dominan, persemakmuran, dan wilayah perlindungan, atau pun sebagai tanah jajahan. Menurutnya, ada sejumlah karya sastra dalam dunia Barat yang turut memperkuat hegemoni Barat (occident) dalam memandang Timur (orient). Sejumlah karya seni itu telah melegitimasi praktik kolonialisme bangsa Barat atas kebiadaban Timur. Penjajahan adalah sesuatu yang alamiah, bahkan semacam tugas bagi Barat untuk memberadabkan bangsa Timur. Dalam bidang sastra, teori postkolonial merupakan salah satu dari serangkaian munculnya kajian atau teori setelah kemapanan teori strukturalisme. Sebagai studi yang kultural, postkolonialisme merupakan wilayah kajian multidisiplin.

Identitas dan isu politik merupakan wacana yang sering muncul dalam ranah postkolonial sebagai konstruksi aspek kolonial, penjajah, dan terjajah. Penjajah yang selalu duduk dalam posisi "subjek", arogan, superior, dan selalu menjadi raja. Alhasil yang terjajah adalah ia yang menjadi objek, inferior, dan selalu menjadi yang di bawah.

Identitas seorang individu dapat diketahui melalui karakteristik fisikras-juga melalui pemikiranpemikirannya. Bentuk identitas yang terdapat dalam wacana postkolonial bersifat oposisi biner-superior dan inferior, meski demikian kondisi biner tersebut dapat memunculkan identitas baru.

Stuart Hall menjelaskan identity politics sebagai the politics of location (Hall, 1996:1) artinya politik menempatkan individu-individu pada lokasi-lokasi (realitas sosial) tertentu yang telah dengan sengaja dikonstruksi. Politik identitas selalu berhubungan dengan the definition of self/subject dalam konstruksi tersebut. Dengan kata lain, politik identitas merupakan pemahaman bahwa identitasidentitas individu didasarkan pada tempat atau posisi di mana individu tersebut diletakkan (place-based identity).

Menurut Madan Sarup, politik identitas atau identity politics merupakan "As politics is about the production of identities-politic produces the subject of its action." (Sarup,1996:48). Artinya politik identitas merupakan politik tentang produksi identitas-identitas, penciptaanpenciptaan subjek beserta tindakan dan nilai yang dipandang baik dan seharusnya dijalani subjek tersebut sebagai sebuah kehidupan yang tidak bisa dipertanyakan. Dalam perspektif social construction of reality, politik identitas dipandang sebagai konstruksi sosial, usaha penciptaan identitas yang dilakukan secara sadar dan melalui berbagai cara, bukan dipandang sebagai sesuatu yang secara alami dianugerahkan oleh Tuhan maupun sesuatu yang sifatnya anatomis.

Jika pandangan Stuart Hall ini dikaitkan dengan pandangan Madan Sarup, maka politik identitas dapat dipahami sebagai produksi identitas-identitas melalui penciptaan tempat-tempat atau posisiposisi subjek dalam lingkungan sosial beserta tindakan-tindakan yang seharusnya dilakukan subjek sesuai dengan tempat dan posisinya tersebut.

\section{Penokohan dan Perwatakan dalam Sastra Indonesia}

Kuntowijoyo (2006:137) mengatakan bahwa sastra Indonesia tidak mempunyai tradisi psikologis yang kuat, dalam arti bahwa penokohan dan perwatakan dalam karya sastra tidak banyak mempersoalkan perkembangan personalitas dari pelaku-pelakunya. Tokohtokoh dalam sastra tidak mempunyai perwatakan yang merdeka, tetapi merupakan tokoh yang sudah ditertibkan. Jika hal ini benar, tradisi pewayangan masih kuat berakar dalam sastra modern kita.

Sebagai imbangan dari ketiadaan tradisi personalisme ini, sastra Indonesia mempunyai tradisi tipologisme. Dalam sastra tipologis para pelaku sudah 
mempunyai personalitas yang mapan, terbentuk sejak ia muncul. Hampir-hampir tidak ada konflik psikis, sebab semuanya sudah didudukkan dalam kerangka personalitas para pelaku. Logika perkembangan pribadi pelaku tidak menuruti pertumbuhan kejiwaan yang penuh dengan krisis yang membentuknya, tetapi menurut kemauan pembentukan sebuah kerangka keseluruhan kejadian. Di sini kejadian sebagai akibat dari hubungan antarmanusia menjadi lebih penting daripada perkembangan kejiwaan pelakupelaku tunggalnya.

\section{HASIL DAN BAHASA N}

1. Shindunata dalam Kesusastraan Indonesia

Dr. Gabriel Possenti Sindhunata, S.J., adalah nama lengkap dari Shindunata. Ia lahir di Kota Batu, Jawa Timur, Indonesia, 12 Mei 1952. Ia telah banyak melahirkan karya sastra di usianya yang mencapai 59 tahun. Putri Cina merupakan salah satu karya dari Shindunata. Novel yang meledak pada awal tahun 2007 diterbitkan oleh Gramedia Pustaka Utama (2007). Novel ini dinobatkan oleh komunitas sastra Bandung, "Nalar", sebagai karya sastra paling bermutu. Tepat sekali bahwa novel ini dipentaskan untuk menandai 100 Tahun Kebangkitan Nasional.

Karya Tulis Shindunata yang lainnya adalah Segelas Beras untuk Berdua, Penerbit Buku Kompas (2006), Dari Pulau Buru ke Venesia, Penerbit Buku Kompas (2006), Petruk Jadi Guru, Penerbit Buku Kompas, Kambing Hitam:Teori Rene Girard,Penerbit Gramedia Pustaka Utama (2006), Burungburung di Bundaran HI, Penerbit Buku Kompas, Ekonomi Kerbau Bingung, Penerbit Buku Kompas, Bola di Balik Bulan, Penerbit Buku Kompas (2002), Bola-bola Nasib, Penerbit Buku Kompas, Air Mata Bola, Penerbit Buku Kompas, Ilmu Ngglethek Prabu Minohek (2004), Mengasih Maria: 100 tahun Sendangsono (2004) - editor, Air Kata-kata (2003),
Jembatan Air Mata: Tragedi Manusia Pengungsi Timor Timur (2003), Long and Winding Road, East Timor (2001), Pendidikan: Kegelisahan Sepanjang Zaman: Pilihan Artikel Basis (2001), Membuka Masa Depan Anak-anak kita: Mencari Kurikulum Pendidikan Abad XXI (2000), Menggagas Paradigma Baru Pendidikan: Demokratisasi, Otonomi, Civil Society, Globalisasi (2000), Sumur Kitiran Kencana: Karumpaka ing Sekar Macapat Dening D.F. Sumantri Hadiwiyata (2000), Sakitnya Melahirkan Demokrasi (2000), Bisikan Daun-daun Sabda (2000), Tak Enteni Keplokmu: Tanpa Bunga dan Telegram Duka (2000), Bayang-bayang Ratu Adil (1999), Menjadi Generasi Pasca-Indonesia: Kegelisahan Y.B. Mangunwijaya (1999), Pergulatan Intelektual dalam Era Kegelisahan: Mengenang Y.B. Mangunwijaya (1999), Cikar Bobrok (1998), Mata Air Bulan (1998), Sayur Lodeh Kehidupan: Teman dalam Kelemahan (1998), Sisi Sepasang Sayap: Wajah-wajah Bruder Jesuit (1998), Semar Mencari Raga (1996), Aburing Kupu-kupu Kuning (1995), Nderek Sang Dewi ing Ereng-erenging Redi Merapi (1995), Hoffen auf den Ratu-Adil: das eschatologische Motiv des "Gerechten Königs" im Bauernprotest auf Java während des 19. und zu Beginn des 20. Jahrhunderts (1992) - Disertasi, Baba Bisa Menjadi Indonesier: Bung Hatta, Liem Koen Hian, dan Sindhunatha, Menyorot Masalah Cina di Indonesia (1988), dan Anak Bajang Menggiring Angin (1983, Gramedia).

Novel Putri Cina ini menggambarkan peralihan kekuasaan di tanah Jawa yang selalu berlumur darah dan pengkhianatan. Ketika raja sudah tidak mampu menghadapi beragam persoalan, maka diperlukan kambing hitam untuk menjaga citranya sebagai seorang raja. Identitas menjadi permainan politik. Manusia terus mengulang sejarah itu dalam konteks politik yang berbeda-beda. Raja memakukan hak otoriter terhadap identitas tunggal yang berbahaya dan juga 
kejam. Pemerkosaan terhadap perempuan etnis Cina juga terjadi waktu itu (Sindhunata, 2007:149-150).

Sejarah kontemporer mencatat pengambinghitaman etnis Cina sejak tahun 1740 (Sindhunata, 2007: 85-86). Ironisnya, identitas selalu dijadikan politik yang berpijak pada kebudayaan. Kebudayaan itu bertumbuh dari perjumpaan antar manusia. Lakon ketoprak Sam Pek-Eng Tay hanyalah satu contoh dialog dalam kebudayaan. Tak ada sekat. Sedangkan ciri fisik hanyalah "kulit" ketubuhan yang membalut pikiran dan jiwa; "dunia kecil" dalam "dunia besar" bernama Semesta yang dibahas sangat dalam di buku ini. Novel Putri Cina ini sebagai "curhat" kaum Tionghoa. Kaum minoritas yang sudah ratusan tahun hidup, menetap di tanah air, tapi masih juga dianggap "orang lain".

\section{Sinopsis Cerita Putri Cina}

Putri Cina ini menggambarkan dua tokoh perempuan yang memiliki lakon berbeda. Tokoh Putri Cina dan Giok Tien menggambarkan dua sosok perempuan berketurunan etnis Cina yang keberadaanya tidak diakui. Tokoh Putri Cina dalam novel Putri Cina diceritakan antara zaman Majapahit hingga kerusuhan Mei tahun 1998. Dia hadir sebagai Putri Campa pada zaman Prabu Brawijaya, Roro Hoyi pada zaman Amangkurat, Eng Tay pada legenda Sam Pek dan Eng Tay, dan hadir sebagai sosok Giok Tien pada masa Kerajaan Medang Kamulan Baru. Tragedi berdarah yang menimpa keturunan etnis Cina ini selalu berulang. Mereka tidak pernah belajar dari sejarah. Sejarah yang membuat mereka celaka. Orientasi etnis Cina yang ada di tanah Jawa selalu mengejar harta dan kekayaan dunia hingga melupakan tradisi leluhur bangsa Cina. Akibatnya, mereka menjadi kelompok kaya elitis yang berada di tengah-tengah mayoritas etnis Jawa yang tertinggal secara ekonomi.

Tragedi cinta antara sepasang kekasih Cina dan Jawa adalah sentral dari novel Putri Cina ini. Tragedi Putri Cina yang diwakili oleh Giok Tien dalam Kerajaan Medang Kamulan Baru menjadi sosok perempuan yang menjadi incaran raja bergelar Amurco Sabdo. Putri Cina digambarkan sebagai istri dari Senopati Gurdo Paksi. Kecantikan yang dimilikinya membuat Raja Amurco Sabdo berhasrat ingin memilikinya. Tidak hanya Amurco Sabdo yang menginginkan Giok Tien, Tumenggung Joyo Sumengah sebagai ketua prajurit pun menginginkan Giok Tien. Keduanya tertarik semenjak Giok Tien menjadi primadona ketoprak keliling Sekar Kastubo.

Cinta Giok Tien yang tidak mengenal batas, bangsa, ras, suku dan agama hanya diserahkan kepada Patih Gurdo Paksi. Hanya dengan kematian cinta mereka berakhir. Dalam legenda Sam Pek dan Eng Tay cinta mereka abadi dan menjelma dalam sepasang kupu-kupu kuning yang terbang ke utara.

\section{Pandangan 0 rientalis terhadap Identitas dan Isu Politik pada Tokoh Perempuan Putri Cina}

(2004:190) kelompok-kelompok subordinat menerima gagasan, nilai-nilai, maupun kepemimpinan kelompok dominan yang bukan disebabkan secara fisik atau mental mereka dibujuk untuk melakukannya, untuk diindoktrinasi secara ideologis melainkan mereka punya alasanalasan tersendiri. Ideologi seseorang yang merupakan suatu gagasan tidak dapat dipaksakan untuk turut terhadap satu kepemimpinan atau kekuasaan, ia berhak atas dirinya. Namun berbeda dengan Putri Cina, identitas yang selalu menjadi permasalahan dalam hidupnya tidak sekaligus membuat ia menjadi selayaknya putri yang dimuliakan oleh rakyatnya, sebaliknya identitas Putri Cina dalam mempermasalahkan keberadaanya yang diikat oleh daging dan darah itu tidak dapat menyatu dengan bumi, sehingga melukiskan dirinya yang hadir namun kehadirannya itu seolah-olah tidak diakui 
oleh tanah tempat di mana ia berpijak. Tragedi anak manusia yang digeluti oleh novel Putri Cina ini melukiskan bagaimana anak manusia itu ingin mencintai bumi tempat ia berpijak tapi bumi tersebut tidak mau menjadi tanah airnya yang aman, damai, dan tentram. Hal ini menjadi sebuah pembicaraan dalam wacana postkolonial karena posisi Putri Cina yang membuat Putri Cina menduduki posisi yang terjajah.

Apa artinya merasa menjadi saudara serumpun dan seluhur, jika mereka tidak punya bahasa yang bisa menjalin mereka untuk saling berbicara? Ia berpikir, andaikan ia dan kaumnya tidak diikat dengan daging dan darah, takkan pernah mereka merasa saling bersaudara. Betapa daging dan darah sama sekali tak cukup untuk menjadikan dirinya sebagai manusia sepenuh-penuhnya. Malahan daging dan darah itu membatasi dia untuk menjadi manusia yang diterima di tempat ia berada. (Sindhunata,2007:10)

Keberadaan Putri Cina terhadap identitas, dipaksakan oleh kultur dominan di luar atas kehendak diri mereka (lingkungan) dan sering kali hal ini termasuk identitas yang merugikan karena nyatanya keberadaan Putri Cina di tengah masyarakat Jawa pun tidak diharapkan, walaupun Putri Cina sudah lama berdiam diri dalam lingkungan tersebut. Posisi Putri Cina yang termarjinalkan dari suatu masyarakat, sehingga eksistensialisme dirinya diragukan untuk hadir di wilayah Jawa. Konsep mawar hitam yang menggambarkan situasi di wajahnya dapat mencerminkan kehidupan yang sudah mati karena masa. Simbol hitam yang berarti warna gelap mengartikan kehidupan yang suram.

Mega-mega berarak, membawa lamunannya terbang jauh ke padang bunga. Segala bunga tumbuh di sana. Satu-satunya bunga yang di sana tak ada adalah mawar hitam yang kini menjadi wajahnya. Di manakah ia ketika tiada lagi wajahnya? Ia pun bertanya, siapakah ia sesungguhnya, dan mengapa ia bernama Putri Cina? (Sindhunata, 2007:14)

Naskah Babad Jaka Tingkir yang tersimpan di Keraton Surakarta itu ada kaitannya dengan Pakubuwana VI, yang lenyap dalam pembuangan Belanda tahun 1830. Kisah Jaka Prabangkara yang membuka kisah Putri Cina adalah bagian dari babad tersebut. Jaka Prabangkara adalah anak Prabu Brawijaya dari seorang selir, yang dibuang ke Cina oleh ayahnya setelah titah sang ayah melukis permaisurinya, Putri Cempa, terlihat begitu sempurna, sampai kepada noda hitam di ujung pahanya. Prabangkara akhirnya menjadi menantu Maharaja Kaisar Cina, menurunkan banyak anak-cucu, yang nantinya berlayar menuju ke tanah leluhurnya, Tanah Jawa. Putri Cina adalah keturunan Prabangkara.

Putri Cina yang diceraikan Prabu Brawijaya adalah ibu dari Raden Patah, penguasa baru Tanah Jawa yang kelak menggulingkan sang ayah. Dia membawa Tanah Jawa menapaki zaman baru, dan oleh para wali diminta menjadi jembatan antara Jawa Lama menuju Jawa Baru, antara agama lama menuju agama baru.

Hal lain yang menunjukkan politik kekuasaan adalah ketika ia dicampakkan oleh suaminya, Prabu Brawijaya yang seorang raja dari Kerajaan Majapahit, dan ditolak oleh keadaan yang merasa membuat dirinya bangga terhadap anak semata wayangnya, Raden Patah.

Terdapat sebuah paradoks di dalam diri Putri Cina atas satu kejadian dalam dirinya bahwa dalam ajaran leluhurnya mengajarkan, orang tua adalah segala-galanya bagi seorang anak karena itu mereka harus dihormati dan dijunjung tinggi. Namun, tidak dalam hal ini. Sebaliknya, Putri Cina menjadi seorang yang tersisihkan di lingkungan darah dan dagingnya sendiri sehingga jelas hal ini 
telah merobek hati Putri Cina sebagai istri dari seorang raja dan ibu yang tidak dapat diakui oleh seorang anak yang berkududukan sebagai pangeran dari Jawa itu.

Ia telah melahirkan penguasa baru dan pembaharu di Tanah Jawa. Tapi mengapa ia tak bisa diakui sebagai ibu penguasa dan pembaharu Tanah Jawa itu, hanya karena ia adalah Putri Cina? Putri Cina tak mampu menghalau kesedihan itu. Memang kesedihannya benar-benar dalam. Ia telah dibuang oleh Prabu Brawijaya. Dan sekarang, anaknya yang lahir dari Prabu Wijaya, yang menjadi penguasa baru di Tanah Jawa itu, juga menyia-nyiakannya sebagai ibu. Itu semuanya terjadi mungkin karena ia adalah perempuan Cina. Itulah kesedihan Putri Cina yang harus ditanggungnya. (Sindhunata, 2007:35)

Sejarah seakan hanyalah panggung, tempat tragika mitos mementaskan dirinya dalam melewati batas waktu yang tidak dapat dipisahkan dengan dirinya yang hanya membawa satu tragedi. Sejarah kerajaan-kerajaan Jawa di masa lalu, menjadi satu isu politik tentang perkembangan kerajaan sejarah di tanah Jawa yang dibumbui mitos-mitos dalam pencarian identitas yang tidak dapat berdiri secara ajeg.

Mitos menurut Barthes (2007: 295) adalah sebuah tipe pembicaraan atau wicara (a type of speech), dapat diartikan bahwa mitos adalah perkataan atau kisah yang diyakini atau dipercayai oleh seseorang. Mitos tidak dapat didefinisikan oleh objek atau pun materi, karena semua hal yang berbentuk pembicaraan dapat disertai dengan makna, baik itu persepsi yang berbentuk tulisan, gambar, film, fotografi, laporan, publisitas, pertunjukan atau pun semua hal yang berfungsi sebagai dukungan pembicaraan dalam mitos. Kegamangan yang dirasakan oleh Putri
Cina dalam upaya pencarian identitasnya ini terkait dengan dirinya yang diragukan oleh mitos seseorang yang Cina dan Jawa sehingga Putri Cina dinilai sebagai objek yang terkungkung karena memiliki kedudukan yang tidak jelas antara Cina dan Jawa. Terbukti keberadaan Putri Cina hanyalah diposisikan sebagai sesuatu yang termarjinalkan dan merupakan satu malapetaka terjadinya perang.

Hal ini terlihat pada percakapan Putri Cina dengan abdinya. Putri Cina yang memiliki kedudukan sama namun tidak sama ini menggambarkan politik kekuasaan yang termakan oleh kegamangan kedudukan karena pengaruh ia yang memiliki identitas sebagai Putri Cina yang Cina juga Jawa. Sebagian narasi dalam buku ini menggunakan bahasa yang dapat dipahami melalui kejawaan. Dialog antara Putri Cina dan SabdapalonNayagenggong dalam beberapa hal membicarakan kejahatan yang tersembunyi dalam diri manusia yang membuat manusia tega berlaku keji pada siapa pun. Keeksistensian dia sebagai seorang putri telah hilang karena posisinya yang Cina dan yang Jawa pula.

"Karena diriku yang tidak jelas ini? Cina bukan, Jawa bukan. Ya jawa, ya Cina. Karena itukah maka aku lain tapi sama dengan mereka?" tegas Putri Cina.

"Benar, Paduka. Begitulah adanya, "jawab SabdopalonNayagenggong.

"Itukah suratan takdirku?" tanya Putri Cina lagi.

"Benar Paduka. Ketika keadaan damai, Paduka adalah manusia seperti mereka karena sama dengan mereka. Tapi ketika keadaan pecah dalam pertikaian, Paduka bukanlah manusia karena Paduka tidak sama dengan mereka," tegas SabdopalonNayagenggong. (Sindhunata, 2007:71)

Dalam hal lain ditemukan bahwa dengan kematian, keberadaanya menjadi 
jelas. Ia tidak harus mempermasalahkan yang berketurunan Cina juga Jawa lagi. Ia berharap kematian adalah jalan pintas terakhirnya yang membuatnya menjadi damai, jauh dari pertentangan-pertentangan atas posisinya yang tidak jelas, sehingga ia tidak perlu merasakan kegelisahankegelisahan yang mengecam dirinya lagi sebagai seseorang yang berkedudukan putri. Ia berharap dengan menemukan kematian, ia dapat menyongsong kehidupan baru yang dapat menghidupinya secara damai.

Memang, dalam perjalanan ke utara untuk menyongsong kematiannya itu, Putri Cina merasa kehidupan itu tak terpisahkan dari kematian, dan kematian itu tak terpisahkan dari kehidupan. Ia sedang menuju kematian, tapi kematian itu akan memberikan kehidupan.

(Sindhunata, 2007:129)

Membaca Putri Cina, narator tidak melakukan penolakan terhadap "identitas" yang didefinisikan pihak di luar dirinya, melainkan merengkuhnya sebagai kerinduan terdalam hati manusia akan sebuah tanah air abadi, yang damai dan tenteram, yang tak pernah memisahmisahkan manusia lagi. Hal ini terlihat pada kutipan penyair Tao Yuan Ming yang berpendapat bahwa manusia bagaikan debu di jalanan.

"Tak berakarlah hidup manusia ini, seperti debu jalanan, kita beterbangan, dibawa angin, ditebarkan ke mana-mana." (Sindhunata, 2007: 302-303).

\section{Pandangan 0 rientalis terhadap Identitas dan Isu Politik pada Tokoh Perempuan Giok Tien dalam Putri Cina}

Identitas seorang individu baik sebagai 'colonizer', 'colonized' maupun ambivalen selalu mengalami perubahan sebab isu mengenai identitas lebih cenderung pada paradigma dan internalisasinya. Oleh sebab itu, Bhabha berpendapat bahwa identitas bukanlah sebuah wacana belaka atau sebuah produk jadi dari sebuah gagasan, melainkan sebuah proses penciptaan 'image' secara totalitas yang terus mengalami permasalahan (1986: xxix-xxxx). Merujuk pada pernyataan tersebut, maka 'image' tidak hanya menjadi isu yang dialami seorang individu sebagai 'colonizer' atau 'colonized' melainkan juga sebagai suatu bangsa yang superior atau inferior.

'Image' suatu bangsa dapat diketahui melalui paparan karya yang ditulis akan tetapi melalui bahasa yang dipergunakan, pola hidup dan pola pikir pula ambivalensi dapat diketahui (Bhabha, 1990: 1). Dengan demikian, karya yang dihasilkan dapat memberikan cerminan atau pemahaman mengenai suatu bangsa berdasarkan isu yang diangkatnya.

Putri Cina lainnya adalah Giok Tien, pemain ketoprak Sekar Kastubo. Hampir setengah bagian terakhir mengeksplorasi kisah Giok Tien, termasuk kisah cintanya dengan pemuda Jawa bernama Setyoko, suami, yang kelak menjadi Senapati Gurdo Paksi di Kerajaan Medang Kamulan Baru. Di sini mitos dan sejarah bergulat menjadi kenyataan hidup. Peran Eng Tay yang dilakonkan Giok Tien dalam ketoprak Sam Pek-Eng Tay adalah lakon hidupnya sendiri. Cinta yang mengikat, cinta pula yang memisahkan. Seperti kesia-siaan. Tokoh sentral pada novel Putri Cina, Giok Tien, istri Gurdo Paksi, sesungguhnya alter ego Koo Soen Ling, ibu kandung Sindhunata sendiri.

Giok Tien adalah perempuan berketurunan raja, istri Gurdo Paksi, yang merupakan prajurit dari panglima Prabu Amuco Sabdo. Giok Tien mengkhawatirkan kejadian sama yang dialami Putri Cina menimpa dirinya pula. Jauh sebelum itu, Giok Tien adalah seorang perempuan Cina cantik yang bekerja sebagai seorang pemain ketoprak. Kepiawaiannya dalam bermain ketoprak telah menjatuhkan mata dari orang-orang yang berperan penting dalam kerajaan.

Menurut Rutherford (1990:225) dalam menanggapi Stuart, identitas adalah 
proses yang meliputi being and becoming. Ia beranggapan bahwa identitas adalah suatu konstruksi yang luwes, sebuah proses yang bukan hanya mengada (being) tapi juga menjadi (becoming) yang mendasari perbedaan mendasar antara "kita ini siapa" dan "kita ini menjadi apa". Proses becoming ini pun terjadi terus menerus tergantung oleh keadaan sosial, budaya, ruang, tempat dan lainnya.

Adalah Radi Prawiro, seorang punggawa keamanan kerajaan yang tergilagila atas pesona kecantikan yang dimiliki oleh Giok Tien, sehingga pada suatu saat Giok Tien dijanjikan hidup enak jika dapat tinggal bersamanya. Namun, tidak secepat itu pula Giok Tien dapat menerima ajakan dari punggawa keamanan kerajaan itu. Identitasnya menjadi seorang Cina tidak dijerat dengan ajakan yang bernilai materialistis. Ia meneguhkan dirinya sebagai seorang Cina yang memiliki harga diri. Bagi ia berdagang merupakan suatu pekerjaan yang telah diajari oleh nenek moyang. Namun, pekerjaannya sebagai pemain ketoprak hanyalah sebagai kendaraannya untuk dapat menjalani kehidupan yang dapat membuat ia senang.

"Aku main ketoprak bukan untuk cari uang. Bila aku ingin hidup enak dan senang, lebih baik aku berdagang. Sebagai anak Cina pasti aku bisa berdagang. Papa dan Mama telah mengajari aku caranya berdagang. Tapi bukan itu yang kucari. Meski tidak banyak uang, hatiku senang, karena aku boleh main ketoprak,"tukas Giok Tien pedas. (Sindhunata, 2007:164)

Politik identitas berkaitan secara erat dengan gagasan atau ide tentang terjadinya penindasan terhadap kelompokkelompok sosial berkaitan dengan identitas mereka (baik berdasarkan ras, etnis, gender, seksualitas, kelas, dll). Artinya, identitas seseorang sebagai seorang perempuan atau sebagai seorang penduduk asli misalnya, membuatnya rentan terhadap imperialisme kultural (termasuk terjadinya stereotipe atau penyalahgunaan identitas kelompok), kekerasan, eksploitasi, serta marjinalisasi atau ketidakberdayaaan.

Giok Tien sebagai perempuan yang waspada dan memiliki harga diri tidak membawa dirinya tenggelam dalam politik kekuasaan. Ia memiliki nilai atas dirinya, sehingga Giok Tien tidak mengalami sebuah pengalaman yang telah teralami oleh Putri Cina. Keberadaannya yang banyak diinginkan oleh laki-laki, lebih memantapkan dirinya agar dirinya harus selalu waspada atas lingkungan sekitarnya. Hal ini selalu diingatkan oleh Korsinah, sahabatnya, tentang kewaspadaan terhadap orang-orang yang berada di sekeliling kita. Dalam hal ini kedudukan Giok Tien bukanlah perempuan yang tertekan atas lingkungannya, sebaliknya ia telah menduduki subjek, sehingga ia bukanlah perempuan yang terjajah.

Oleh para penggemar ketoprak, Giok Tien tidak hanya dikagumi tapi juga dicintai. Ia tentu bangga karenanya, tetapi seperti dipesankan Korsinah, di tengah kebanggaan itu ia mesti tambah waspada. Sebab ternyata semakin ia terkenal, makin banyak laki-laki yang mencoba menggoda dan mendekatinya. (Sindhunata, 2007:178179)

Kaum Putri Cina dijadikan kambing hitam, tumbal, dalam perebutan kekuasaan. Giok Tien, pemain ketoprak di Malang, akhirnya menjadi incaran banyak laki-laki, terutama Jawa. Dua komandan tentara pun ikut berebut. Dan akhirnya Giok Tien menjadi istri Gurdo Paksi. Sebagai istri senapati kerajaan tak membuat Putri Cina aman dan damai. Dua saudara kandungnya--Giok Hong dan Giok Hwa--dibunuh oleh manusia bertopeng. Begitu pula kerumunan rakyat membakar toko-toko, rumah-rumah, milik kaumnya Giok Tien. Kejadian perkosaan dilakukan terhadap kaum Putri Cina. Giok Tien adalah perempuan Cina halus dan beretika. Kecantikannya telah membawa Prabu Amurco Sabdo padam atasnya. Segala 
kekayaan dan kesenangan yang dimilikinya tidak sekaligus membuat Giok Tien dengan mudah untuk meninggalkan suaminya. Hal ini menandakan bahwa Giok Tien adalah seorang istri yang setia atas suaminya. Ia adalah seorang perempuan yang teguh pendirian, tidak digoyahkan oleh kenyataan yang materialistis. Kekuasaannya tidak dapat digoyahkan oleh budaya materialis.

"Paduka, ingatlah ini bukan panggung ketoprak. Di negeri ini Paduka sungguh pemimpin dan raja yang terhormat. Jangan Paduka seperti seorang pemain sandiwara yang harus berperan memainkan diri sebagai perayu wanita,"kata Giok Tien, sambil menghindar dari sergapan Prabu Amurco Sabdo (Sindhunata, 2007:248).

Menolak kolonialisasi, tindakan yang masuk akal adalah melakukan perjuangan melalui persamaan dalam perekonomian dan kebebasan sosial sehingga kedudukan dari 'colonizer' dan 'colonized' berada dalam derajat yang sama. Tindakannya tersebut, kemudian, akan membuatnya menjadi pihak yang inferior di kalangannya sendiri sehingga memiliki identitas yang ambivalen. Giok Tien adalah seorang perempuan yang memiliki identitas atas kuasa dirinya. Kecantikannya sebagai Putri Cina membuat Joyo Sumenggah, panglima Medan Kamulan, berusaha untuk menguasai Giok Tien. Pada waktu itu Giok Tien dan Gurdo Paksi mati dibunuh Joyo Sumenggah, dalam krisis politik berujung pembersihan etnis. Dalam cinta, Giok Tien menemukan identitas makna keberadaannya. Dalam cinta pula Gurdo Paksi menemukan identitas sejatinya sebagai Setyoko. Dalam cinta itu luluh segala perbedaan bahkan hanya dalam cinta itu harta, kegagahan, keperkasaan dan kuasa memiliki makna. Tanpa cinta, semuanya itu bagai keris Kyai Pesat Nyawa. Keris yang selama ini menjadi andalan kedigdayaan Joyo Sumengah itu justru membawa ke kehancurannya. Gerbang pintu kematian telah membawa Giok Tien dalam keadaan yang damai.

Namun diluar perkiraannya, Giok Tien mendorong tubuh suaminya, sehingga anak panah yang dilepaskannya menyasar ke dada Giok Tien. Dan binasalah Giok Tien mendahului kematian suaminya. (Sindhunata, 2007: 294)

Gerakan-gerakan yang dipandang sebagai politik identitas, memandang telah terjadi penindasan dan berusaha merekomendasikan dilakukannya klaim ulang, deskripsi ulang, atau transformasi ulang terhadap catatan-catatan keanggotaan kelompok yang sebelumnya distigmatisasikan. Putri Cina sendiri nyaris diperkosa oleh Joyo Sumengah, saingan berat Gurdo Paksi sejak masih sama-sama bertugas di Malang. Lolos dari tangan Joyo Sumengah, Putri Cina alias Giok Tien akhirnya diperkosa dan dirusak martabatnya oleh Prabu Amurco Sabdo, orang nomor satu di Kerajaan Medang Kemulan. Gurdo Paksi memergoki perbuatan bejat sang raja. Amurco Sabdo pun lengser keprabon, diganti orang kepercayaannya. Namun, Joyo Sumengah diam-diam bersama anak buahnya menghabisi pasangan suami-istri CinaJawa yang sedang bersemayam di makam Giok Hong dan Giok Hwa. Giok Tien meninggal lebih dulu terkena anak panah, disusul Gurdo Paksi.

"Ya, begitulah Gurdo Paksi dan Giok Tien telah menjadi sepasang kupu-kupu. Itulah mereka, anak Cina dan Jawa, yang cintanya tak terpisah, menjadi sepasang kupukupu yang amat indah. Cinta memang tak mengenal perpisahan. Kemiskinan dan kekayaan tak pernah memisahkan Sam Pek dan Eng Tay. Cinta Giok Tien dan Gurdo Paksi pun tak pernah bisa dipisahkan kendati mereka adalah Cina dan Jawa. Sampai mati pun mereka tetap berdua, terbang menjadi sepasang kupu-kupu." (Sindhunata, 2007:299) 


\section{PENUTUP}

Identitas adalah jati diri, sesuatu yang kemudian perempuan sadari sebagai persoalan internal psikologis, juga ternyata adalah eksternal sosio-kultural, karena mereka berada dalam persoalan tarik-ulur harapan dan kenyataan.

Identitas diri adalah apa yang selalu dalam proses mencari esensi. Putri Cina hanya representasi kaumnya. Merasa gamang tanpa akar, terpaksa menerima fakta menyandang identitas kultural dan ragawi tertentu, terserak di tempat yang terasa salah, dan dikambing-hitamkan. Itulah konteks hidup dan pergulatannya. Putri Cina gundah dengan pencarian akan identitas. Dalam pergulatan mencari identitas itu ia merasa seperti debu yang terbang dibawa angin, terserak di luar kuasanya, karena ternyata identitas itu menjadi permainan politik diskriminasi yang kejam.

Tokoh perempuan yang diperankan oleh Putri Cina dan Giok Tien ini mencitrakan identitasnya dengan citra perempuan secara fisik, perilaku, psikis, dan sosial. Citra fisik Putri Cina adalah seorang perempuan Cina yang sangat cantik jelita, berperilaku baik dan lemah lembut, taat kepada ajaran agama, dan di lingkungan sosialnya. Putri Cina sangat disenangi oleh para abdi dan orang terdekatnya, sedangkan tokoh Giok Tien digambarkan sebagai seorang perempuan Cina yang cantik, berperilaku baik, setia terhadap suami, dan mudah bersosialisasi dengan orang-orang pribumi.

Dengan demikian, Peran Putri Cina mununjukkan isu politik dalam proses pembauran etnis yang ikut menyumbangkan perubahan di tanah air, sedangkan peran Giok Tien dalam proses pembauran etnis adalah ikut mengharumkan nama kesenian Jawa, yaitu ketoprak.

\section{UCA PA N TERIMAKA SIH}

Artikel yang berjudul "Pandangan Orientalis dalam Penokohan dan Perwatakan Tokoh Perempuan dalam Putri Cina Karya Sindhunata" ini untuk melengkapi persyaratan akademik untuk dapat mengikuti sidang akhir tesis untuk memperoleh gelar Magister Humaniora pada program Pascasarjana Fakultas Ilmu Budaya Universitas Padjadjaran Program Studi Ilmu Sastra Kajian Utama Sastra Kontemporer.

Saya menyampaikan ucapan terima kasih secara khusus kepada:

1. Dosen pembimbing, Ibu Aquarini Priyatna, M.A. Ph.D dan Dr. Lina Meilinawati Rahayu yang telah membimbing dan memberikan masukan untuk tulisan saya.

2. Dewan Redaksi Jurnal Patanjala dan Mitra Bestari yang telah menerima dan memproses jurnal saya untuk dapat dimuat di Jurnal Patanjala.

\section{DAFTAR SUMBER}

Barthes, Roland. 2007. Membedah Mitos-mitos Budaya Massa. Yogyakarta: Jalasutra.

Bhabha, Homi. K..1994.

The Location of Culture. London: Routledge Classic.

Hall, Stuart. 1996.

Introduction: Who Needs 'Identity'? dalam Stuart Hall dan Paul Du Gay, (eds), Question of Cultural Identity. London: Sage Publication.

Kuntowijoyo. 2006.

Budaya dan Masyarakat. Yogyakarta: Tiara Wacana.

Meij, Lim Sing. 2009.

Ruang Sosial Baru Perempuan Tionghoa Sebuah Kajian Pascakolonial. Jakarta: Yayasan Obor Indonesia.

Nazir. 1988. Metode Penelitian.Jakarta: Ghalia.

Ratna, Kutha. 2004. 
Teori, Metode, dan Teknik Penelitian Sastra. Yoyakarta: Pustaka Pelajar.

Ratna. Prof. Dr. Nyoman Kutha. 2004.

Sastra dan Cultural Studies.

Yogyakarta: Pustaka Pelajar.

Ruthorford, Jonathan. 1990.

Identity:Community, Culture, Difference. London: Lawrence and Wishart.

Sarup, Madan. 1996.

Identity, Culture and The Postmodern World. Athens: The University of Georgia Press.

Said, Edward. 1978.

Orientalism. London: Penguin.

Selden, Raman., Peter, W. dan Sindhunata. 2007.

Putri Cina. Jakarta: Gramedia Pustaka Utama.

Strinati, Dominic. 2004.

Popular Culture. Yogyakarta: Bentang.

Wellek, Rene. Warren, Austin. 1956.

Theory of Literature. New York: A Harvest Book. 